\title{
Renal ultrasound imaging in a preterm infant with a persistently elevated $\mathrm{C}$ reactive protein
}

\author{
Sagarika Ray, Shiva Shankar
}

Department of Neonatal Medicine, The Shrewsbury and Telford Hospital NHS Trust, Telford, UK

Correspondence to Dr Sagarika Ray, sagarika.ray@nhs.net

Accepted 10 May 2018

\section{DESCRIPTION}

A preterm infant born at $25+5$ weeks gestation was being treated for late onset sepsis on day 30 She had just recovered from an episode of necrotising enterocolitis, requiring a 14-day course of intravenous antibiotics. She was on biphasic non-invasive respiratory support and fully enterally fed on expressed breast milk. During this time, she was noted to have a rising $\mathrm{C}$ reactive protein (to maximum of $114 \mathrm{mg} / \mathrm{L}$ ), high white cell count (highest count $26.2 \times 10^{9} / \mathrm{L}$ ) and thrombocytopaenia (lowest count $63 \times 10^{9} / \mathrm{L}$ ), in spite of being treated with second-line intravenous broad-spectrum antibiotics (meropenem and vancomycin) for 14 days. She did not receive antifungal prophylaxis during her admission. Blood and cerebrospinal fluid cultures showed no growth. Urinalysis showed no growth on bacterial and fungal culture and no filamentous fungi were noted on microscopy. She remained clinically well. A cranial and abdominal ultrasound scan was undertaken on day 35. The abdominal ultrasound revealed a lesion in the left kidney (figure 1) which was characteristic of a renal fungal ball.

Even though blood culture and urine culture were negative, the infant received intravenous fluconazole for 2 weeks and oral fluconazole for the subsequent 2 weeks in view of the renal ultrasound scan findings. The renal lesions disappeared on a follow-up scan after 4 weeks of antifungal treatment. The inflammatory markers reduced to normal limits within a week of initiation of antifungal treatment. Repeat urine cultures were taken 3 weeks after starting treatment and a week after cessation of treatment, and they did not show any fungal growth.

Some infants are at higher risk of fungal infections, especially those who are preterm, immunocompromised, have indwelling catheters, prolonged antibiotic therapy or with congenital abnormalities of the urinary tract. ${ }^{1}$ The most common organism is Candida species. Antifungal prophylaxis is not universally practised in neonatal units in the UK, due to the lower incidence of invasive fungal infection compared with other countries and there are concerns regarding the development of resistance. The diagnosis of systemic fungal infection in high-risk neonates may be delayed as signs and symptoms may be non-specific. Moreover, although culture from a clinical sample is the gold standard for the diagnosis of a fungal infection, cultures can be negative in many cases with high proportions of false-negative results and low sensitivities. ${ }^{2}$ However, persistence of thrombocytopaenia and an elevated $\mathrm{C}$ reactive protein should warrant a suspicion of invasive fungal infection. $^{3}$

In invasive candidiasis, there may be renal pyramidal involvement, especially in the region of the papillae, which may slough and fungal balls may develop in the collecting systems. The renal ultrasound during a fungal infection can show non-acoustic echogenic debris in the collecting systems. ${ }^{1}$ This may sometimes
D Check for updates

To cite: Ray S, Shankar S. BMJ Case Rep Published Online First: [please include Day Month Year]. doi:10.1136/bcr-2018225164

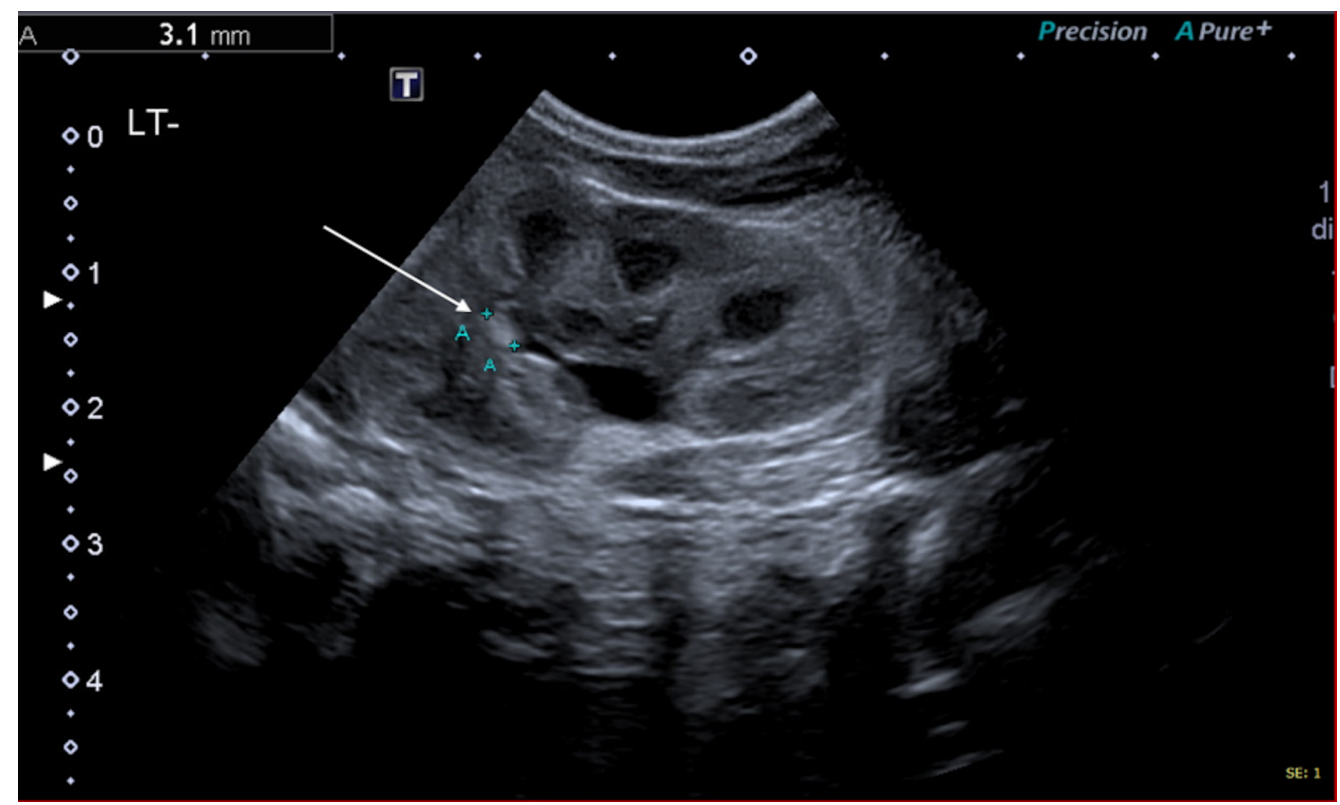

Figure 1 Ultrasound imaging of the left kidney. 


\section{Learning points}

- Maintain a high index of suspicion and consider invasive fungal infection in preterm infants who present with signs consistent with sepsis or necrotising enterocolitis while on antibiotic therapy, even in the absence of positive cultures of fungi or other micro-organisms.

- Fungal balls on a renal ultrasound have a characteristic appearance and can help to confirm the diagnosis of invasive fungal infection and indicate the resolution of infection.

be associated with an obstructive nephropathy or uropathy due to pelviureteric obstruction or renal failure. The rate of sonographic improvement is variable and can range from 10 days to 4 months. However, this rate does not correlate with clinical course, longterm renal function or necessitate longer term therapy. Differential diagnoses include pyogenic debris, blood clot, tumours and nephrocalcinosis.
Contributors SS identified the case and image. SR undertook the literature search and drafted the manuscript. Both SS and SR revised, reviewed and approved the final manuscript.

Funding The authors have not declared a specific grant for this research from any funding agency in the public, commercial or not-for-profit sectors.

Competing interests None declared.

Patient consent Guardian consent obtained.

Provenance and peer review Not commissioned; externally peer reviewed.

(C) BMJ Publishing Group Ltd (unless otherwise stated in the text of the article) 2018. All rights reserved. No commercial use is permitted unless otherwise expressly granted.

\section{REFERENCES}

1 Daneman A, Navarro OM, Somers GR, et al. Renal pyramids: focused sonography of normal and pathologic processes. Radiographics 2010;30:1287-307.

2 Sidiq F, Hoostal M, Rogers SO. Rapid identification of fungi in culture-negative clinical blood and respiratory samples by DNA sequence analyses. BMC Res Notes 2016;9:293.

3 Benjamin DK, Fisher RG, McKinney RE, et al. Candidal mycetoma in the neonatal kidney. Pediatrics 1999;104(5 Pt 1):1126-9.

Copyright 2018 BMJ Publishing Group. All rights reserved. For permission to reuse any of this content visit http://group.bmj.com/group/rights-licensing/permissions.

BMJ Case Report Fellows may re-use this article for personal use and teaching without any further permission.

Become a Fellow of BMJ Case Reports today and you can:

- Submit as many cases as you like

- Enjoy fast sympathetic peer review and rapid publication of accepted articles

- Access all the published articles

- Re-use any of the published material for personal use and teaching without further permission

For information on Institutional Fellowships contact consortiasales@bmjgroup.com

Visit casereports.bmj.com for more articles like this and to become a Fellow 